\title{
Forum
}

\section{Rereading conservation critique: a response to Redford}

I was delighted to be invited to write this response and further encouraged by Kent Redford's (2011) invitation to social scientists to engage the full diversity of what multiply variegated conservation communities have to offer. I agree that achieving more holistic understandings of complex conservation problems will be greatly facilitated through more holistic understandings of one another, our motivations, and how we understand the world. Portraying someone as 'a beleaguered inhabitant of a fortress,' (Redford, this issue) or a critic establishing their credentials by 'bagging a BINGO' (Brosius, 2007), is not the best approach. Abandoning such portrayals is an important step towards creating, in Redford's words, '. . . a resilient practice that conserves the world's biodiversity while respecting and empowering people'.

Although inspired by this vision, I am puzzled by Redford's decision not to attribute the arguments and ideas he invokes to specific critiques and writings. This renders his important essay slippery, both for building on points of agreement and for constructively engaging his own misreadings. As Redford's vision calls for greater clarity on all sides I would like to highlight some exchanges and ideas that could promote such clarity by fostering 'productive tensions' (Igoe et al., 2009) for future collaborations. My offerings, pace Redford, are 'not meant to be exhaustive but illustrative', focusing on four key points: (1) the putative division between conservationists and social scientists, (2) how diverse communities are made to appear homogeneous, (3) conservation and capitalism, and (4) related distributions of fortune and misfortune.

In my experience conservationists and social scientists are not distinct communities but inhabit interconnected networks. These cross-cut institutional boundaries and connect in turn to diverse groups of people. Acknowledging this reality highlights that critiques of conservation cannot be neatly construed in terms of insiders and outsiders. Critical insights are often derived from transformations and learning by conservationists themselves. Sachedina (2010), for instance, worked for the African Wildlife Foundation for 6 years before presenting his analysis of problems in East African conservation. Annette Lees of the Austral Foundation and activist Siliana Siwatibau (2010) wrote about the paradoxical effects of large conservation NGOs in Fiji.

JAmes IgOe 6047 Silsby Hall, Hanover, NH 03755, USA. E-mail james.j.igoe@dartmouth.edu
Wildlands co-founder David Johns (2009) actually suggested that there is no conservation community and that slick marketing will never succeed in building the kinds of social movements that will be necessary if we really hope to achieve sustainably the kinds of 'resilient practice' that Redford invokes.

Apropos of Johns' concerns one interesting contribution of social science is helping to understand ways in which conservation is often constructed to conceal its own diversity. Researchers have pointed to significant discrepancies between the representation and practice of conservation (Benjaminsen \& Svarstad, 2010), and the tendency to recast complex political struggles as technical problems amenable to bureaucratic interventions orchestrated by experts (Brosius, 1999). Another important issue is the management and concealment of dissent at high profile events such as the World Conservation Congress (McDonald, 2010) and the ways in which a vision of win-win market-based solutions is celebrated and disseminated in the process (Buscher, 2008; Redford \& Adams 2009).

This brings me to connections between conservation and commerce, which Redford correctly notes are not new. It is important to understand how the commoditization of nature has changed over time (cf. Redford \& Adams, op cit) but at least as important to understand the specific forms this commoditization is taking right now (for an overview see Brockington \& Duffy 2010), particularly those forms that promise to make the world healthy and beautiful through consumption and investment. Neves (2010), for instance, outlines how presentations of whale watching as an enlightened alternative to whale hunting conceals paradoxes such as the carbon footprint of air travel and the effects of tour boats on cetacean echolocation (cf. Carrier \& Macleod, 2005). My work (Igoe 2010) examines how images of conservation promote the possibility of eating our world and saving it too. Finally, Sullivan (2010) highlights the contradictions of financial mechanisms such as carbon credits (see also Checker, 2009), species banks and extinction derivatives. All of this work is directly concerned with conservation beyond the boundaries of parks, and especially the notion that conservation can mitigate the negative ecological impacts of shopping malls, oil pipelines, gold mines and the like.

There are also questions concerning the ways in which costs and benefits of these transformations are distributed. Such questions are not served by asserting that parks, and 
conservation interventions in general, are all the same and always bad for people living near them but by recognizing that outcomes in any context are related to specific cultural, historical and political circumstances (West et al., 2006). Attending to these will foster more informed understandings of how best to promote conservation that is effective and equitable. Related debates are currently a matter of some productive exchanges, beginning with a study by Wittemeyer et al (2008). This study, which suggests that parks are generally beneficial to local people, has garnered critical responses from ecologists and social scientists, encapsulated in a special issue of Conservation and Society edited by Hoffman et al. (2011). This ongoing exchange reveals that a lot more work needs to be done before we can safely generalize about these matters.

Finally, I would like to suggest some resources for readers who would like to learn more, and to raise a question for continued engagement. Firstly, the resources: the IUCN Commission on Environmental, Economic and Social Policy publishes an accessible journal called Policy Matters that offers extensive analysis and empirical case studies of the human side of conservation; Current Conservation is a journal dedicated to making research and news from the natural and social sciences accessible to a broader audience; and Just Conservation is a Facebook initiative dedicated to providing an open forum for achieving conservation with justice. Secondly, the question: given all this nuanced analysis, what is preventing more effective communication and engagement? This is a question that calls for careful reflection on all sides but also more open acknowledgement of the relative power of different people, disciplines and organizations in different contexts to show and tell what conservation is about and how it affects both human and more than human worlds.

\section{References}

Benjaminsen, T. \& Svarstad, H. (2010) The death of an elephant: conservation discourses versus practices in Africa, Forum for Development Studies, 37, 385-408.

Brockington, D. \& Duffy, R. (2010) Capitalism and conservation. Antipode, 42, 469-484.

Brosius, J.P. (1999) Green dots, pink hearts: displacing politics from the Malaysian rainforest. American Anthropologist, 101, 36-57.

Brosius, J.P. (2007) Reflections on conservation, displacement, and exclusion. In Protected Areas and Human Displacement: A
Conservation Perspective (eds K. Redford \& E. Fearn), pp. 106-112. Wildlife Conservation Society Working Paper 29, New York, USA. Http://www2.fiu.edu/ brayd/wcswp29.pdf [accessed 2 May 2011].

BUSCHER, B. (2008) Conservation, neoliberalism, and social science: a critical reflection on the SCB 2007 Annual Meeting in South Africa. Conservation Biology, 22, 229-231.

Carrier, J. \& MacLeod, D. (2005) Bursting the bubble: the sociocultural context of eco-tourism. Journal of the Royal Anthropological Institute, 11, 315-334.

CHecker, M. (2009) Double jeopardy: carbon offsets and human rights abuses. Counter Punch. Http://www.counterpunch.org/ checkero9092009.html [accessed 11 May 2011].

Hoffman, D., FAY, D. \& Joppa, L. (2011) Introduction: human migration to protected areas edges in Africa and Latin America: questioning large-scale statistical analysis. Conservation and Society, 9, 1-7.

IGOE, J. (2010) The spectacle of nature in the global economy of appearances. Critique of Anthropology, 30, 375-397.

Igoe, J., Sullivan, S. \& Brockington, D. (2009) Problematizing neoliberal biodiversity conservation: displaced and disobedient knowledge, Current Conservation, 3(3), 4-8.

Johns, D. (2009) A New Conservation Politics: Power Organization Building and Effectiveness. Wiley-Blackwell, Oxford, UK.

Lees, A. \& Simatibau, S. (2009) Strategies for effective and just conservation: a summary of Austral Foundation's review of conservation in Fiji. Current Conservation, 3(3), 21-23.

MCDonald, K. (2010) Business, biodiversity, and the new fields of conservation: the World Conservation Congress and the renegotiation of organizational order. Conservation and Society, 8, 256-275.

Neves, K. (2010) Cashing in on cetourism: a critical ecological engagement with dominant e-NGO discourse, on whaling, cetacean conservation, and whale watching. Antipode, 42, 719-741.

Redford, K.H. (2011) Misreading the conservation landscape. Oryx, $45,324-330$

Redford, K. \& Adams, W. (2009) Payments for ecosystem services and the challenges of saving nature. Conservation Biology, 23, $785-787$.

SAchedina, H. (2010) Disconnecting nature: the scaling up of the African Wildlife Foundation and its impact on biodiversity conservation and sustainable livelihoods. Antipode, 42, 603-623.

Sullivan, S. (2010) The environmentality of Earth Incorporated. Paper presented to the Conference: A Brief Environmental History of Neoliberalism, Lund University, Lund, Sweden, 6-8 May 2010. Http://siansullivan.wordpress.com/publications/capitalism-andbiodiversity-conservation/ecosystem-services/ [accessed 30 April 2011].

West, P., Igoe, J. \& Brockington, D. (2006) Parks and people: the social impact of protected areas. Annual Review of Anthropology, 35, 251-277.

Wittemyer, G., Elsen, P., Bean, W., Burton, A. \& Brashares, J. (2008) Accelerated human population growth at protected area edges. Science, 321(5882), 123-126. 